\title{
QUERE⿱ Division
}

A Highry successful MEeting of the Quebec Division was held at Lévis on February 15 The programme opened with guided touns of the magnificent new wing of the Hôtel-Dieu de Lévis, and the remainder of the morning was then given over to a general meeting, under the chairmanship of the President of the Division, Dr Paul Galibois

Though many of the matters discussed were predominantly of local interest, It is perhaps worth noting that active steps were takeh to encourage recruitment to our specialty To this end a leaflet has been prepared which outlines what is entailed in the practice of the specialty, the nature of the training required, and the plethora of openings throughout the Province The Quebec Division has authorized the distribution of the pamphlet to junior internes and senior medical students, and is most grateful to the Charman of the University Departments at Laval, McGll, and Montreal, under whose guidance the project has been realized quickly and skilfully

The afternoon programme, attended by more than 100 members, featured a varied and enjoyable scientific menu, consisting of papers, in the first place, by our own members

"Intravenous Regional Anaesthesı"-Dr Jeah-Claude Poulot
"Direct Current Atrial Defibillation"-Dr André McClish
"The Anaesthetist and His Patient"-Panel Dr Leon Longtin
(Chairman), assisted by Drs Lucien Rinfret, Michel Boisvert,
Eugène Allard, Jean-Paul Couture, and Florian Poirier

These were followed by our guest speaker (and one time colleague), Dr Allen B Dobkin, now Professor of Anesthesiology at the University of Syracuse, who delivered a most comprehensive survey on "Sedatives, Analgesıcs, Antidotes, and Therr Interaction"

During the day the ladies travelled to Lac Beauport, where lunch was served at the Manoir St Castin, followed by a tour of points of interest in Quebec City No finer tribute could be pard to the superb arrangements made by $\mathrm{Dr}$ Irenée Lapierre than to mention that more than 160 (members, wives, and guests) sat down for dinner at the Motel Rond-Point Our very welcome guests of honour on this occasion were Dr Rosaure Gingras, Dean of Laval's Faculty of Medicine, Dr J B Jobin, President of the College of Physicians and Surgeons of the Province of Quebec, Dr J A Fafard, Governor of the College for the district of Lévis, and $M$ Gérard Barbin, Director of the Institut Cooperatif Desjardins, whose hospitality we had enjoyed earlier in the evening

After dinner the gathering was enthralled well into the wee hours of the morning by the magnificent voice and appearance of Mlle Marcelle Couture, a native of nearby Charny, and the enthusiasm generated by this charming entertainer obviously rubbed off on all piesent, if one could judge from their subsequent behaviour on the dance floor 


\section{NOUVELLES DU QUÉEEC}

Le 15 févner dernıer, la division du Québec de la Société Canadienne des Anesthésıstes tenait ses assıses d'hiver à l'Hôtel-Dieu de Lévis

Un groupe imposant d'anesthésistes répondait à l'invitation du docteur Irénée Lapierre, bien connu pour son enthousıasme et son affabilité, le docteur Lapierre présida lu1-même à tous les détails de l'organısation matérielle, et la réunıon fut un succès Le docteur Lapierre ne pouvalt décevorr'

Nous avons eu l'occasion de visiter la nolivelle arle de l'Hôtel-Dieu de Lévis, nous avons constaté que cette construction, sans luxe superflu, répond bien aux besoins et du malade et des médecins

A l'assemblée générale, la discussion porta suı le recrutement de nouveaux membres et sur la perception des tarifs et hoporares Des propositions et amendements de membres relatuvement nouveaux dans la division ont prouvé qu'un sang jeune et combatif a été infusé à la Société et que l'esprnt qui l'anime est bien adapté au siècle que nous vivons ( $A$ bon entendeur, salut!)

La réunın scientifique était dirigée par le Dr Paul Galıbois, notre dévoué présıdent Les docteurs J C Poullot et Andié McClısh nous ont parlé respectıvement de "L'Anesthésie régionale intraveine ise" et de "La Défibrillation aunculaure par courant direct" Puis, nous avons clssisté à un colloque sur "Le Malade et son anesthésiste," présıdé par le Dr Léon Longtin, assisté des docteurs $\mathbb{L}$ Rinfret, M Boisvert, $\mathbb{E}$ Allard, J -P Couture et Flonan Poiner

Le Dr Allen B Dobkin, qui fut l'un des nôtres et qui est maintenant professeur au University of Syracuse, était le conférencier invité Il présenta un travall fort élaboré sur le sujet suivant "Sedatıves, Analgesıcs, Antidotes and Their Interaction" Nous aurons le plassir de le lire dans notre journal, nous a-t-1l assuré Merci à luı' Je ne voudrais pas passer sous silence son film sur la ıéanımation massage cardiaque externe et respiration artificielle $\mathrm{La}$ mise en scène et la réalısation maténelle de ce film sont vraiment remarquables il ménte d'être projeté dans nos institutions

La partie récréative fort variée n'a pas éte négligée tant par le nombre que par l'enthousiasme de l'assistance Mentionnons la visite de Québec organisée pour les dames, le dîner au Lac Beauport, le coquetel et la visite de l'Instıtut coopératıf Desjardins et, comme couronnement, le banquel au motel Rond Point Parmi les invités d'honneur, on remarquart le Dr Rosaire Gingras, doyen de la Faculté de Médecine de Laval, le docteur J - $\mathbb{B}$ Jobın, présıdent du Collège des Médecins et le Dr J -A Fafard, gouverneur du Collège pour le district de Lévis

A l'Hôtel-Dieu de Lévis, au docteur Irénée Lapierre et à tous ceux qui ont contribué au succès de cette réunion, félicitations et remerciements 